\title{
Fundamental Principles of American Law
}

\author{
Patrick M. McFadden $\dagger$
}

In all types of legal writing, whether by scholars or by practitioners, it is customary to cite an authority or authorities to show support for a legal or factual proposition or argument.

\section{-The Bluebook: A Uniform System of \\ Citation 4 (16th ed. 1996)}

With the cool detachment of anthropologists describing human sacrifice among the Maya, the editors of the Bluebook thus calmly report on that peculiar human custom of legal citation. The self-interested nature of the editors' report-providing an apology for both the 365 pages and steady royalty income that follow-makes it no less accurate. But the measured tone of the report does underplay the significance of legal citation to those who must actually do it-an importance that ranges from cultish obsession to defeated indifference. Some of us never lose the zeal of the newly converted, compulsively searching every legal text for canonical purity. Others of us become equally ardent schismatics, embracing, for example, the Maroon heresy. Still others lapse in the faith, either making a principled decision that there are better ways to spend our time or simply feigning contempt because we can't for the life of us remember if the space goes between the " $F$." and the "2d" or the "F." and the "Supp."

But one thing is certain: we all complain. Law review editors grouse about the mindless tedium and thanklessness of cite-checking, ${ }^{1}$ while authors whine about the tyranny of jump cites, parentheticals, and

Copyright (c) 1997 California Law Review, Inc.

$\dagger$ Professor of Law, Loyola University Chicago School of Law. Several reputable scholars reviewed earlier drafts of this article. It is not in their interest to reveal who they were nor in mine to reveal their reactions. My sincere and explicit thanks, however, to Alexandra and Stanley Mamangakis, who for the past three summers have provided me a cool, quiet office in Greece. Just don't tell them I wrote this, too.

1. See, e.g., E. Joshua Rozenkranz, Law Review's Empire, 39 Hastings L.J. 859 (1988) (containing, inter alia, a former editor's brief tirade on footnote work, with special bonus sections on alienation and the reproduction of hierarchy). Wonder who got to Josh? 
the editorial obsession to footnote everything. ${ }^{2}$ I suggest that we all pipe down and approach this matter like the mature, stouthearted men and women that we most certainly are. Sure, there are problems with law review footnotes, but let's just roll up our sleeves and take care of them. ${ }^{3}$

This Article, for example, solves one of the biggest problems in legal scholarship: the need to find authority for statements that are obviously true or completely unsupportable. ${ }^{4}$ What legal writer or editor has not struggled to find cites for propositions like "the world is becoming increasingly complex" or "justice delayed is justice denied"? Therefore, as a public service, this author and the California Law Review now provide (i) a soberly-titled article, (ii) in a highly regarded journal of legal opinion, (iii) that states the obvious and argues the unsupportable. No more combing through Bartlett's Quotations, ${ }^{7}$ no more desperate searches through the World Almanac and Book of Facts, ${ }^{8}$ or God forbid, Corpus Juris Secundum. ${ }^{9}$ Everything you need is here, ${ }^{10}$ and if

2. See, e.g., John E. Nowak, Woe Unto You, Law Reviews!, 27 ARIz. L. Rev. 317 (1985) (excoriating law review scholarship and predicting little chance for improvement-persuasiveness undercut by lack of footnotes). Professorial complaints about law review style have become as common as drive-by shootings, and you can find the articles for yourself. But do not miss the "Goodbye" series, inspired by Fred Rodell: Fred Rodell, Goodbye to Law Reviews, 23 VA. L. REv. 38 (1936) (swearing off law reviews); Fred Rodell, Goodbye to Law Reviews-Revisited, 48 VA. L. Rev. 279 (1962) (author caught in a lie, but unrepentant); Abner J. Mikva, Goodbye to Footnotes, 56 U. CoLo. L. Rev. 647 (1985) (swearing off footnotes in judicial opinions); Abner J. Mikva, Goodbye to Footnotes: Relinquishing a Tradition, TrIAL, Aug. 1986, at 46 (in case you missed it the first time); Richard A. Posner, Goodbye to the Bluebook, 53 U. CHI. L. REv. 1343 (1986) (swearing off the Bluebook); Charles Alan Wright, Goodbye to Fred Rodell, 89 YALE L.J. 1455 (1980) (confirming that what goes around comes around).

3. Cf. Places in the HeART (Tri-Star 1984) (former flying nun does what it takes to bring in the cotton and save the farm).

4. "The [law review] author may not assert so much as 'The sun rises in the east' without citing Copernicus." Ron Coleman, Citing Cites That Cite Cites: Are There Any New Ideas in Legal Scholarship?, Student Law., Feb. 1989, at 13. And if you don't believe journalist Ron Coleman, Professor Delgado fills the breach: "Essentially, each assertion of law or fact that you make in the body of your article will require a footnote." Richard Delgado, How to Write a Law Review Article, 20 U.S.F. L. Rev. 445, 451 (1986). He's serious, though he does, in a big-hearted sort of way, make exceptions for "topic sentences, conclusions of paragraphs and sections, and passages of pure argument." Id.

5. See Patrick M. McFadden, Fundamental Principles of American Law, 85 CALIF. L. REv. 1749,1752 (1997) (reporting that the law is becoming increasingly complex).

6. See id. (confirming that justice delayed is justice denied).

7. John BARTlett, FAmiliar Quotations (Justin Kaplan ed., 16th ed. 1992).

8. The World Almanac and Book of Facts 1997 (1996).

9. As Morris Cohen has been telling us for years, the rule for legal encyclopedias is "look, but don't touch." See, e.g., MORRIS L. COHEN ET AL., How to Find THE LAw 386 (9th ed. 1989) (proclaiming that legal encyclopedias "have come to be viewed primarily as research tools, useful for case-finding and as introductions to research, but not as independent authority"). Woe to the scholar who cites American Jurisprudence, thus to suffer the steely gaze of Marjorie Rombauer. See Marjorie Dick Rombauer, Legal Problem Solving 166 (5th ed. 1991) (waming that legal encyclopedias are "never" to be cited in "scholarly material").

10. But see The Beatles, All You Need Is Love, on Magical Mystery Tour (Capitol 1967) (suggesting that love is all you need). 
it's not, there is something close enough for a $C f$. cite." Even if you could find the needed citations for yourself or command a sycophantic research assistant to do so, why bother? Now, for the first time ever, almost every obvious or unsupportable statement you will ever need can be found in one highly reputable place.

A simple demonstration will confirm the incalculable value of such an effort:

The world is becoming increasingly complex.

Justice delayed is justice denied.

Like shooting ducks in a barrel. Both propositions now have the backing of the California Law Review. I myself have used these propositions already, which you can confirm by returning to footnotes five ${ }^{12}$ and $\operatorname{six}^{13}$ and accompanying text. Best of all, this Article helps not only you, the support-starved reader, but me, the promotion-starved author. ${ }^{14}$ You can now drag yourself out of any scholarly hole you dig, and I get to grab for the brass ring in Fred Shapiro's next update of "The Most-Cited Law Review Articles"15 in America. The California Law Review cleans up, too. ${ }^{16}$

The next section of this Article has several important features. First, an introductory paragraph provides some nauseatingly pretentious and thoroughly vapid claptrap about the foundations of American law. But that's what the title of this Article promises, and that's what I intend to

\section{For example,}

The theory of language determines the theory of the text. The real being of literature occurs in the temporal hearing of words. The literary text is oral speech heard in time. As image, as print, as object of mastery, the word appears in an invidious spatial guise. But as an evanescent sound activated in and through body and mind, the literary word comes into its proper temporal being. Cf. Patrick M. McFadden, Fundamental Principles of American Law, 85 CALIF. L. REv. 1749 (1997) (discussing fundamental principles of American law).

This passage (without the cite) was selected at random and stolen from VINCENT B. LEITCH, DeCONSTRUCTIVE CRITICISM 81 (1983) (containing a whole lot more where that came from). Vince, I think, could have used a little extra support.

12. See supra note 5 and accompanying text. Must you be told everything twice?

13. See supra note 6 and accompanying text; see also supra note 12 (incisively criticizing the reader for slavishly reading every footnote).

14. Actually, that's misleading. I've already climbed to the top of the charts. See Letter from James S. Wiser, Executive Vice President and Dean of Faculties, Loyola University Chicago, to Patrick M. McFadden, Associate Professor of Law, Loyola University Chicago School of Law (Feb. 28,1996 ) (announcing the author's promotion to full professor) (on file with author and author's attorney); see also Laurence J. Peter \& Raymond Hull, The Peter Principle (1969) (explaining my promotion and a great deal more about my law school; yours, too, I imagine). Despite its uselessness on the promotion front, frequent citation to this Article can't hurt when my Dean (Nina S. Appel, an extraordinarily perceptive and, may 1 add, hardworking and underappreciated administrator) ladles out the annual pool of merit raises. But 1 digress.

15. Fred R. Shapiro, The Most-Cited Law Review Articles, 73 Calif. L. Rev. 1540 (1985).

16. Which explains its apparent lapse in judgment in accepting this piece: everyone has a price. Cf. Johann Wolfgang von Goethe, FAusT (Barker Fairley trans., Univ. Toronto Press 1970) (1808) (recounting German citizen's regrets over bad deal). 
deliver. Second, the same paragraph provides a couple of long footnotes, quite out of character with the rest of the piece. These footnotes will look like strings of completely unrelated, randomly selected cases from federal and state courts. This is because they are strings of completely unrelated, randomly selected cases from federal and state courts. They are designed to provide weighty citations in your future work. You can give the appearance of having struggled with a group of difficult cases, or at least bask in the reflected glow of my hard work, by dropping a footnote that reads: "See, e.g., Patrick M. McFadden, Fundamental Principles of American Law, 85 CALIF. L. REv. 1749, $1754 \mathrm{n} .1$ and cases cited therein." There are two such footnotes ahead, in case you need to show balance: "But see id. n.2 (citing further cases)." Third-and this is the heart of the piece-you will find a series of high-minded phrases and patently obvious facts. These passages are arranged in roughly the order you will need them in any future article, beginning with your topic's importance to the life of the nation and concluding with profound reflections on law and society. As could be expected, these high-minded phrases and patently obvious facts often run at cross-purposes, and frequently contradict each other entirely. You will, therefore, need to make substantial use of ellipses when you lift your quotes.

Now listen. If our little plan here is going to work, we all have to pretend that we didn't see the first part of this Article. We have to pretend, from now on, that I have written a carefully conceived, thoroughly researched article that seeks to plumb the very foundations of American law. It is therefore crucial that you razor out everything in this Article between the title (leave my name) and the end of this paragraph. The editors and I have even taken the precaution of beginning the next paragraph with footnote number one (" 1 "), ${ }^{17}$ so we are pretty certain that the subterfuge will work. Now dig around for that razor from your first year of law school and get to work. Do it now.

$$
\text { *** }
$$

17. See infra note 1 (a law review first). 
American law is founded on a series of factual premises, political axioms, and juridical principles that are seldom stated explicitly but that infuse and inform our legal discourse. ${ }^{1}$ In this Article, I will canvass those premises, axioms, and principles ${ }^{2}$ and, by collecting them all in one place, lay the groundwork for later studies. Such studies, crucial to our understanding of American law, will not only map the hermeneutical and epistemological relations between the premises, axioms, and principles, but will subject them, both individually and collectively, to internal as well as external critique.

There is nothing so important, nothing so worthy of serious study, as the law's treatment of the family. There is nothing so important, nothing so worthy of serious study, as the law's treatment of commerce. There is nothing so important, nothing so worthy of serious study, as the law's treatment of public wrongs, private wrongs, public power, private power, private property, international relations, race relations, gender relations, and the stewardship of natural resources.

\section{II}

This study is important because the law of torts, property, contracts, decedents' estates, and commercial enterprise, as well as civil procedure, criminal procedure, and our revenue laws, say something important about us as a society. The message is clouded, however, because the law of torts, property, contracts, decedents' estates, and commercial

1. See, e.g., Barenblatt v. United States, 360 U.S. 109, 134 (1959) (holding that Congressional witness could properly be convicted of contempt for refusing to answer questions about his affiliations with Communist Party); Partee v. San Diego Chargers Football Co., 668 P.2d 674, 675-76 (Cal. 1984) (determining that state antitrust law does not apply to interstate activities of professional football team); Wieser v. Missouri Pac. R.R. Co., 456 N.E.2d 98, 104-05 (1ll. 1983) (reversing lower court's refusal to grant defendant's forum non conveniens motion); State v. Galloway, 708 P.2d 508, 513 (Kan. 1985) (deciding that criminal defendant was given a speedy trial); Miller v. Catholic Diocese, 728 P.2d 794, 797 (Mont. 1986) (affirming dismissal of teacher's wrongful discharge complaint against operator of parochial school); People v. Rodriguez, 424 N.Y.S.2d 600, 608 (Sup. Ct. 1979) (granting lawyer-priest's motion for permission to wear clerical garb while defending client in court).

2. See, e.g., The Paquete Habana, 175 U.S. 677, 700 (1900) (declaring that international law is part of United States law); The Fairisle, 76 F. Supp. 27, 31 (D. Md. 1947) (determining amount and distribution of salvage award for refloating of ship), aff $d$ sub. nom Waterman S.S. Corp. v. Dean, 171 F.2d 408 (4th Cir. 1948); Wakefield v. Little Light, 347 A.2d 228, 237-38 (Md. 1975) (upholding lower court judgment refusing jurisdiction over custody of Native American child found domiciled on reservation in Montana); Crechale \& Polles, Inc. v. Smith, 295 So. 2d 275, 277 (Miss. 1974) (holding that landlord's election to treat holdover tenant as trespasser could not later be changed to treat holdover as tenant for new term); McBride v. Clayton, 166 S.W.2d 125, 130 (Tex. Comm'n App. 1942) (deciding that dissolved corporation had lost insurable interest in decedent executive before executive's death and that former shareholders were not permitted to share in insurance proceeds). 
enterprise, as well as civil procedure, criminal procedure, and our revenue laws, have been buffeted by the winds of change.

\section{III}

Our society has grown increasingly diverse. Our society has grown increasingly complex. Our lives have grown increasingly complex. The rate of social and political change has escalated dramatically. The world is getting smaller. Income disparities between rich and poor grow everwider. Western hegemony is fast disappearing. The end is near.

\section{IV}

The law, however, has not adapted. The law has adapted more slowly than we might have wished. The law wisely resists every transitory change in the social wind.

\section{V}

Yet the law must always adapt to new conditions or be rendered irrelevant or worse. At the same time, men and women arrange their affairs on the basis of the laws as they stand, even those of dubious wisdom, and such laws cannot be changed without overturning well-settled expectations and disrupting important legal relations.

\section{VI}

In the final analysis, the law must be fair. Our efforts to ensure the law's clarity and predictability can never justify unfairness in the individual case. In the final analysis, the law must be clear and predictable, even at the expense of individual litigants. Without clarity and predictability, the law becomes corrosively unfair to us all.

\section{VII}

The ordinary meaning of a word or phrase must be given effect. To do otherwise risks interpretive chaos and impermissibly shifts lawmaking authority from the statehouse to the courthouse. The surest way to misread a law is to read it literally.

\section{VIII}

Overturning precedent destabilizes long-settled expectations and cuts against the rule of law. Blind adherence to precedent can never be justified. 


\section{IX}

All law is politics. In one sense, of course, all law is politics, but they are not exactly the same. Law and politics, while related, are different fields of human endeavor. Despite the reductionist impulse to collapse law into politics, they have little to do with each other. The law stands on its own, as it must.

\section{$\mathrm{X}$}

American law has been disfigured by endemic racism, sexism, ethnocentrism, xenophobia, homophobia, and the imperialistic demands of mature capitalism. "Systemic" critiques of American law are based on a category mistake: particular laws, but not all law, can be characterized as racist, sexist, ethnocentric, xenophobic, homophobic, or imperialistic. We have come a long way. We still have a long way to go.

$\mathrm{XI}$

The law has stunted economic growth and hampered free exchange. Economically inefficient laws are bad laws. Economic concerns are important, but not decisive. Economic concerns are relevant, but they are always trumped by non-economic values. Economic analysis is simply irrelevant.

\section{XII}

The sun rises in the east and sets in the west. It's always several hours later in Europe. Tomorrow is another day.

Now get back to work, and worry about something more important. 
CALIFORNIA LAW REVIEW 